\title{
ADVANCES IN THE STUDY OF \\ VESICULAR-ARBUSCULAR MYCORRHIZA $^{1}$
}

\author{
B. Mosse \\ Department of Soil Microbiology, Rothamstead Experimental Station, Harpenden, \\ Herts., England
}

\section{INTRODUCTION}

The study of vesicular-arbuscular (VA) mycorrhiza is expanding rapidly. Since Gerdemann's review in 1968, over a hundred papers have been published. During previous five year periods numbers were: 14 (1930-4), 22 1935-9), 17 (1948-52), 43 (1953-7), 56 (1958-62) and 40 (1963-7). These are small numbers considering how long it has been known that VA mycorrhiza are probably the most widespread root infections of plants. With some justification they have been described as the "mal aimée des microbiologistes" (22).

The increase in publications has been accompanied by a shift in subject matter. Most papers, until recently, described the anatomy and recorded the occurrence of VA mycorrhiza, and many efforts were made to culture the fungi; since 1968, 37 papers have dealt with effects of the infection on plant growth.

Several factors probably account for the increased popularity of the subject. The long-standing speculation about the identity of VA endophytes (47, 56) has largely been resolved in favor of one or another species of Endogone $(32,46,95)$. Very impure inocula consisting of infected roots or of soil containing a normal population of other soil micro-organisms, have been replaced by Endogone spores, sporocarps, or "sterilized" soil inoculated with them in the presence of a host plant. Such inocula now regularly produce typical VA infections in experimental plants. With improved techniques, very striking effects of inoculation on plant growth and phosphate uptake have been demonstrated beyond doubt, and this has led to studies of the uptake mechanism and the source of the extra phosphate. These results have also stimulated interest in the fungi themselves, their ecology and taxonomy. The technique of clearing roots in $\mathrm{KOH}$ before staining $(24,77,120,121)$ is now

'I thank my colleague Dr. D. S. Hayman for many helpful discussions. 
widely used and has led to more general awareness of the frequency of VA mycorrhiza in many crop plants. Finally, three very good reviews $(47,57$, 115) have drawn attention to the potentialities of VA mycorrhiza and helped to raise their study to the level of "a reputable pursuit" (57).

\section{EFFECTS OF VA MYCORRHIZA ON PLANT NUTRITION}

Improved growth of plants with VA mycorrhiza has been obtained in soil ( 5 , $12,13,19,31,32,45,46,64,93)$, in peat and sand $(25)$, in sand $(34,90$, 153 ) and in water culture (119). Gerdemann (47) has described the gradual improvement in techniques and discussed some of the technical difficulties that arise from the need to remove indigenous mycorrhizal fungi from most soils, and the inability to culture Endogone species on synthetic media. Whereas soils used to be "sterilized" by autoclaving or steaming, they are now usually "sterilized" by $\gamma$ irradiation $(60,61,101,102,104,108,123$, $131)$, fumigated with methyl bromide $(32,41)$, chloropicrin and methyl bromide $(73,127,128)$ treated with aerated steam $(73)$, or steamed between electrodes (16-18). Effects of inoculation in nonsterilized soil have also been examined $(40,45,66,71-73,108,110,136)$. Most experiments have been in pots, but a few $(71-73,127,136)$ have also been in field plots. Spores of a species of Endogone are now generally used as inoculum. They are multiplied in association with a host plant in "sterilized" soil or sand in greenhouse pots, and are often applied together with particles retained after wet sieving on sieves of selected mesh sizes $(17,34,45,51,60)$. Ross \& Harper (128) raised their inoculum monoxenically in closed jars, and Jackson, Franklin \& Miller (66) used lyophilized, ground, infected roots. Filtered washings from the inoculum, containing many of the contaminating organisms, are usually added to the controls; Clark (32) and Baylis (17) added crushed spores.

Baylis (12), Gerdemann (45), and Holevas (64) first suggested that the improved growth of plants inoculated with VA mycorrhiza might be due to increased phosphate uptake. More recently the uptake of phosphate from Pdeficient soils, from different sources and amounts of added phosphate, and from isotopically labelled soils and solutions has been studied in some detail.

\section{Phosphorus}

UPTAKE FROM UNAMENDED sorl Many plants take up more phosphate and grow better in soils containing little available phosphate when inoculated with VA endophytes. This occurred with onions and Coprosma grown in 10 different soils (60), with Griselinia (12), maize $(45,71)$, strawberries (64), soyabeans (in one of two soils) (128), wheat (72) and with grape vine (123). Other plants responsive to inoculation have been the tropical grasses, Paspalum notatum $(101,102)$ and Melinis minutiflora (109), the tropical legume, Centrosema pubescens (109), Citrus spp. $(73,86)$, Liquidambar styraciflua (52), Agathis australis $(14,92)$, Liriodendron tulipifera $(30,31,46$, 
52), Podocarpus $(14,19)$ and Araucaria sp. $(25,26)$, walnut (136), tobacco $(9,119)$, tomato $(34)$, barley $(21)$ and oats $(90)$. There are also records of negative $(80,90)$, variable $(152)$, or no response $(60)$, especially after adding phosphate $(64,71,72,104,127)$.

It is well known that different plant species $(8,42,67,146,154)$, and even varieties of the same species $(81,137)$, differ in their ability to extract phosphate from the same soil; some species will show phosphate deficiency symptoms while others grow normally. The reasons are not fully understood, although root distribution and geometry may play some part (10). Even in solution culture, plant species can differ in their ability to take up phosphate at low concentrations $(7,126)$. It is therefore not surprising that they also differ in their response to VA infection. In an agricultural soil I found that Liquidambar, onions, and Coprosma responded to inoculation with up to tenfold growth increases, whereas Nardus stricta and Fuchsia were little improved. The responsive species also grew better with added phosphate, but nonresponsive ones did not. In a much less fertile beach sand, however, growth of Nardus was also much improved by inoculation (T. H. Nicolson, private communication). Baylis (16) reported a similar lack of response to mycorrhizal infection in six plant species grown in a soil where Coprosma robusta grew much better with mycorrhiza than without. Four of the nonresponsive species, however, grew better with added phosphate. He related mycorrhizal response to root hair development, and suggested that plants with poorly developed root hairs may be obligatory mycotrophs in P-deficient soils. Later, however, he found that in another soil containing only half as much available $\mathrm{P}$, the "nonresponsive" Leptospermum scoparium also responded to inoculation. In a final experiment, Baylis (18) studied the growth responses of five plant species to three levels of added phosphate. The results suggested that the species fell into three groups according to their requirements for a minimum threshold value of available $P$, below which they grew very little. He thought this threshold value might relate to the root:soil interface. An interaction between root geometry and the amount of available soil $\mathbf{P}$ would then determine the likely response to mycorrhizal inoculation. Plant species and levels of available phosphate in the soil or growth medium are thus likely to determine plant response to mycorrhiza.

Responses to inoculation were small $(45,136)$ or not significant $(127)$ in nonsterile soil if the inoculum was mixed with the soil at planting. Responses were as large or even larger than in "sterilized" soil, however, with rough lemon and Troyer citrange (73) and with onions, already mycorrhizal at planting or sown on a cushion of inoculum $(108,110)$. Khan $(71,72)$ found that mycorrhizal maize and wheat seedlings planted in a field grew much better and yielded more grain than uninoculated seedlings.

Increasing the weight of inoculum ten-fold (128), or varying spore numbers from 3 to 225 (36), had no significant effect on dry weight of soyabeans, or on dry weight, percent of infection, and P uptake in twelve-week-old tomato plants. Even one spore may constitute an "effective inoculum" (36). 
UPTAKE FROM SOILS OR MEDIA GIVEN EXTRA PHOSPHATE Three aspects have been studied in some detail: $(a)$ the effects of soluble phosphate on infection, phosphate uptake, and growth of mycorrhizal and nonmycorrhizal plants, (b) the effects of different sources of phosphate, and (c) the placement of inoculum and rock phosphate. In general, adding soluble phosphate improves growth of mycorrhizal plants less than that of nonmycorrhizal ones $(13,35$, $64,71,72,104,113,127)$; it sometimes even reduces the growth of the mycorrhizal plants. It also tends to reduce infection in both pot $(13,26,35,104)$ and field $(71,72,74-76,127)$ experiments. This may be due to high phosphate concentrations in the host $(104,112)$.

Hayman \& Mosse (60) compared the responses of onions to mycorrhiza and to phosphate in ten irradiated P-deficient soils in a pot experiment. Monocalcium phosphate was given at the rate of $0.4 \mathrm{~g} / \mathrm{kg}$ soil (approx. equivalent to $221 \mathrm{~kg} \mathrm{P} / \mathrm{ha}$ ). All plants were also fed with a complete nutrient solution lacking phosphate. Mycorrhizal plants grew as well in three soils, in one they grew better, and in six worse than those given phosphate. Clearly the mycorrhiza extracted different amounts of phosphate from the different soils, and in six soils it was insufficient for optimum growth.

That responses to inoculation and to phosphate can differ with the soil was also shown in another pot experiment in which $0,0.2,0.5,1.0$, and $1.5 \mathrm{~g}$ monocalcium phosphate $/ \mathrm{kg}$ soil were added to both mycorrhizal and nonmycorrhizal plants in four irradiated soils (104). Mycorrhizal plants in all soils without added phosphate were several times larger than nonmycorrhizal. Plants in all soils, whether mycorrhizal or not, reached a maximum weight with $0.2,0.5$, or $1.0 \mathrm{~g}$ of monocalcium phosphate, and weighed less when 1.5 $\mathrm{g}$ was given. In agricultural and grassland soils, plant $\mathbf{P}$ concentrations rose relatively slowly, and mycorrhizal plants weighed more than nonmycorrhizal at all levels of added phosphate. In soils from a forest plantation and a heath, plant $\mathbf{P}$ concentrations rose much higher, and with optimum amounts of added phosphate nonmycorrhizal plants grew much better than mycorrhizal. These results were explained on the assumption, suggested by a previous experiment with nonmycorrhizal plants, that plant $\mathbf{P}$ concentrations in onions can rise to levels that adversely affect growth. With the larger additions of phosphate, mycorrhizal infections decreased and, after very large phosphate additions, their appearance was changed; arbuscules first became fewer, then all intracellular infection disappeared, and eventually infection was restricted to certain specialized cells in the sub-epidermal layer. With $1.5 \mathrm{~g}$ added phosphate infection virtually disappeared from the roots, although the soil remained infective.

Similar results occurred in pot experiments with Coprosma (13), where much phosphate reduced infection and caused growth of the infected plants to fall below that of the uninfected. Adding monocalcium phosphate and superphosphate increased the $\mathrm{P}$ concentration, but not the weight of mycorrhizal, as compared to nonmycorrhizal maize (113). Adding phosphate to a 
sand:soil mixture made the growth and $P$ uptake of mycorrhizal and nonmycorrhizal strawberry plants equal (64).

An unusual response to nitrogen and phosphate occurred in Araucaria cunninghamii grown in a peat:sand mixture (25). Neither mycorrhizal nor nonmycorrhizal plants responded to phosphate unless a minimum amount of nitrogen was given. Mycorrhizal plants then responded greatly to additions of 5 ppm P, but grew no better with 50 ppm P. Nonmycorrhizal plants re-

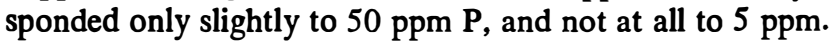

Daft \& Nicolson (35) examined the effect of different amounts and times of application of potassium dihydrogen phosphate on the growth of mycorrhizal maize in sand. Plants were fed with a nutrient solution lacking phosphate and were also given a basic dressing of the relatively insoluble tricalcium phosphate. With all additions of potassium phosphate, nonmycorrhizal plants grew as well as mycorrhizal, but without it they grew worse. The added phosphate increased plant weight, but decreased mycorrhizal infection by up to $50 \%$ and spore production up to $80 \%$, in direct relationship to the amount of phosphate given but irrespective of the time of application. If the highest dosage was given in one application, these effects were more marked the earlier the application.

Pot experiments are unnatural in providing a limited volume of soil in which the phosphate is so evenly distributed that roots cannot grow away from it. Similar results have, however, also been obtained with soyabeans grown in $1.5 \mathrm{~m}^{2}$ bins and given 0,44 , and $176 \mathrm{~kg} \mathrm{P} / \mathrm{ha}$ (127). Yield and weight of nonmycorrhizal plants increased steadily with increasing $\mathbf{P}$ additions, while that of mycorrhizal plants, and the number of extra-matrical spores attached to their roots, were progressively reduced. The mycorrhizal plants weighed more at harvest and yielded more seed than nonmycorrhizal plants given $44 \mathrm{~kg} \mathrm{P} / \mathrm{ha}$. Khan (71) obtained similar results with inoculated maize seedlings planted in a field containing natural infection. At all times during this experiment, plant weight, percent of $P$, and ear size were greater in unfertilized inoculated maize than in control plants given $250 \mathrm{lb} /$ acre triple superphosphate $(40 \mathrm{~kg} \mathrm{P} / \mathrm{ha})$. Inoculated plants with fertilizer again grew worse than those without, and the fertilizer greatly reduced infection in all plants. Similar responses occurred in wheat (72).

Nitrogen $(59,79)$, complete fertilizer $(2,78)$, and bacterial fertilizer (135) can also reduce mycorrhizal infection in the field. Small additions of nutrients to very nutrient-deficient soils or media can, however, increase infection both in field $(2,139)$ and pot experiments $(26,119,136)$, probably by improving plant growth. Whether or not such a stimulation occurs probably depends on the nutrient level in the soil, and the amount of growth a particular plant can make in it.

The formation of VA mycorrhiza in clover seedlings in agar cultures also depended on the nutrient content of the medium $(95,103,112)$. With $0.2 \mathrm{~g} / 1$ $\mathrm{K}_{2} \mathrm{HPO}_{4}$ and $1 \mathrm{~g} / 1 \mathrm{CaHPO}_{4}$, infection occurred only when there was no ni- 
trogen and when fungal entry was assisted by a culture of bacteria, a cell-free extract from a bacterial culture, or by EDTA (95). If, however, the calcium phosphate content was reduced to $0.5 \mathrm{~g} / 1$ and no potassium phosphate was given, infection readily occurred in the presence of potassium nitrate (112). Some infection occurred also without any added phosphate, but both seedling growth and infection were improved by small phosphate additions. As in field and pot experiments, large amounts of phosphate decreased infection. High phosphate concentrations in the plant appeared to make it immune to infection (103). Experiments with transplanted seedlings of different $\mathbf{P}$ content confirmed that inability to infect in media containing much phosphate is a result of changed plant metabolism or structure rather than a direct effect of phosphate on the fungus.

UPTAKE FROM DIFFERENT SOURCES Daft \& Nicolson (34) found that mycorrhizal tomatoes responded greatly to small additions of bonemeal, but their relative advantage over nonmycorrhizal plants decreased when 16 and 32 times as much bonemeal was given. Relative improvements in growth were greatest with tricalcium phosphate, less with finely ground apatite, and least with the more soluble dicalcium phosphate. With the relatively insoluble tricalcium phosphate, mycorrhizal maize grew much better than nonmycorrhizal (113). The difference was less with rock phosphate and, given the more soluble monocalcium- and superphosphate, plants with and without mycorrhiza grew equally well. It was inferred from these experiments that, like other micro-organisms $(1,54,144)$, the mycorrhizal fungus might be able to utilize insoluble phosphates.

Utilization of rock phosphate was also studied in a placement experiment with maize, soyabeans, and sorghum grown in nonsterile soil in 4-liter containers (66). Soyabeans did not respond to inoculation, but grew better when the phosphate was distributed through the soil than when it was concentrated in bands. Sorghum responded slightly to inoculation, and maize markedly, if either the rock phosphate was distributed throughout the soil and the inoculum added as a concentrated layer, or if both were distributed through a 5 cm layer of soil. With rock phosphate placed in narrow bands, both inoculated and noninoculated maize grew badly.

It has also been suggested that mycorrhiza might utilize organic forms of phosphate. In sand in open pots, where some organic phosphates might quickly be broken down by bacteria, most of the organic phosphates tested were equally available to mycorrhizal and nonmycorrhizal onions (62). Although phosphate concentrations of the mycorrhizal plants were quite often higher than the nonmycorrhizal plants, their growth was not appreciably better, except with inorganic Gafsa rock phosphate; it was considerably worse with glucose-6-phosphate and RNA. Mycorrhiza did, however, greatly improve growth of plants in sand amended with humus, soil from the A horizon, or, to a slightly smaller extent, leaf litter. 
UPTARE FROM ISOTOPICALLY LABELLED SOLUTIONS The uptake of ${ }^{32} \mathrm{P}$ has been studied from solutions $(28,52,92)$, from soil injected with a labelled solution of phosphate (53), and after adding a fungitoxic substance (53). After exposure times of 30 min $(28,92)$ to 4 days (52) mycorrhizal clover and Liriodendron roots, and detached mycorrhizal nodules of Agathis australis contained about twice as much activity as nonmycorrhizal. Uptake was halved at $1{ }^{\circ} \mathrm{C}$ but the difference between mycorrhizal and nonmycorrhizal nodules remained (92). After 40 days growth in a soil injected with labelled phosphate, leaves of mycorrhizal Liquidambar contained 15 times more activity than nonmycorrhizal (52). The greatest difference occurred in onions previously starved of phosphate. Roots and shoots of plants exposed for 90 hours to a labelled phosphate solution contained 160 and 45 times more activity, respectively, when the plants were mycorrhizal (53). Mycorrhizal root segments contained 25 times more activity than nonmycorrhizal segments on the same plant, but the latter contained 20 times more activity than segments from nonmycorrhizal roots. Adding parachloronitrobenzene reduced uptake into mycorrhizal roots to the level of nonmycorrhizal roots.

These results confirm that mycorrhizal roots take up more phosphate than nonmycorrhizal, and that this is translocated to the shoots. The effects of the fungitoxicant strongly suggest that it is the fungus that absorbs the extra phosphate. Autoradiography of sections of mycorrhizal roots confirms this $(3,28)$. Labelling was strongest in hyphae, both within and outside the roots, and was particularly concentrated in the arbuscules. In both studies, however. the labelling of the fungus was uneven.

UPTARE FROM ISOTOPICALLY LABELLED soIL By adding carrier-free ${ }^{32} \mathrm{P}$ to soils it is possible, after thorough mixing and a period of equilibration, to label the "labile" pool of soil phosphate, which contains the phosphate utilized by plants. Insoluble and organic forms of phosphate are not labelled. If a plant, by virtue of its mycorrhiza, was able to utilize such generally unavailable sources of phosphate, the activity per unit of phosphate taken up would be less than in a plant drawing only on the labelled pool. It is thus possible to determine whether mycorrhizal and nonmycorrhizal plants utilize different fractions of the soil phosphate. This was done in three experiments $(21,61$, 131).

The specific activity of phosphorus in ten-week-old mycorrhizal and nonmycorrhizal plants in each of eight soils was very similar, though it differed from soil to soil (61). Using one of these soils, Sanders \& Tinker (131) found that, throughout the period of their experiment, the specific activity of phosphorus in mycorrhizal and nonmycorrhizal onions was the same, although inflow rates were 3-16 times greater in the mycorrhizal plants. These experiments show that mycorrhizal and nonmycorrhizal plants utilized the same or similarly labelled fractions of soil phosphate, and that mycorrhizal plants did not utilize sources of phosphate unavailable to plants without my- 
corrhiza. Sanders \& Tinker (131) concluded that the greater inflow rates could not be attributed to increased activity of the mycorrhizal roots, but that entry into and subsequent transport through external hyphae must occur. The simplest theory to account for the extra P uptake, therefore, is that the mycelium outside the root constitutes an additional, better-distributed surface for absorbing $\mathbf{P}$ from the soil solution. ${ }^{2}$

In a very unusual soil in which plant species differed in their ability to utilize the slowly available P, Benians \& Barber (21) found that mycorrhizal barley grew better than nonmycorrhizal, and that the specific activity of the phosphorus in mycorrhizal plants tended to be lower.

Because of the widespread view that mycorrhiza can solubilize unavailable phosphate, we (109) repeated the experiment in some Brazilian soils containing extremely small amounts of $\mathrm{NaHCO}_{3}$ - and $\mathrm{CaCl}_{2}$-soluble P. Again there was no indication that mycorrhizal plants used different sources of phosphate. However, some species (e.g., Centrosema pubescens and Paspalum notatum, but not Melinis minutiflora) took up no phosphate at all from these soils unless plants were mycorrhizal. It appears that some plants have a threshold concentration of $\mathbf{P}$ in the soil solution below which they do not take up phosphate. This concentration is lower for the mycorrhizal fungus or root, or there may be no threshold value at all. Experiments of Beslow, Hacskaylo \& Melhuish (23) support this conclusion. In perlite sub-irrigated with a nutrient solution containing $1 \mathrm{ppm} P$, red maple seedlings weighed no more than those irrigated with distilled water only. Their weight increased progressively with 5,10 , and $20 \mathrm{ppm} \mathrm{P.} \mathrm{The} \mathrm{beaded} \mathrm{roots} \mathrm{of} \mathrm{red} \mathrm{maple} \mathrm{are} \mathrm{com-}$ monly mycorrhizal (VA).

\section{Other Nutrients}

The uptake of other nutrients can also be affected by mycorrhiza. Peach seedlings in Yolo loam fed with a nutrient solution containing $\mathrm{N}, \mathrm{P}, \mathrm{K}, \mathrm{Ca}$, $\mathrm{Mg}, \mathrm{B}$, and Fe EDTA grew very little and showed severe symptoms of zinc deficiency unless they were inoculated with an Endogone sp. and became mycorrhizal (51). Three-year-old inoculated seedlings showed no symptoms of zinc deficiency, weighed nearly twice as much, and contained 2-3 times as much zinc as noninoculated seedlings. ${ }^{3}$

'In a recent review of phosphate pools, phosphate transport and phosphate availability (Ann. Rev. Plant Physiol. 1973, 24:), R. L. Bieleski calculated that with four hyphal connections per $\mathrm{mm}$ root and hyphae extending $20 \mathrm{~mm}$ from the root surface, $P$ uptake would increase about $60 \times$ if diffusion were limiting and $10 \times$ if uptake were proportional to surface area.

${ }^{8}$ Mycorrhizal soyabean plants took up more ${ }^{\circ 0} \mathrm{Sr}$ than nonmycorrhizal after 1, 3, and 7 days contact with ${ }^{\infty} \mathrm{Sr}$ amended soil, whether sterilized or not. Lyophilized mycorrhizal roots were used as inoculum. (Jackson, N. E., Miller, R. H., Franklin, R. E. 1973. The influence of vesicular-arbuscular mycorrhiza on uptake of ${ }^{\infty} \mathrm{Sr}$ from soil by soybeans. Soil Biol. Biochem. 5:205-12) 
Differences in $\mathrm{N}, \mathrm{K}, \mathrm{Ca}, \mathrm{Na}, \mathrm{Mg}, \mathrm{Fe}, \mathrm{Mn}, \mathrm{Cu}, \mathrm{B}, \mathrm{Zn}$, and $\mathrm{Al}$ concentrations of mycorrhizal and nonmycorrhizal plants have been reported $(12,40$, $45,64,66,73,93,127,128)$. Results are, however, inconsistent, with the possible exception of copper, which generally reaches greater concentrations in mycorrhizal plants, and manganese which is generally lower. All these results are subject to the criticism that plants were not really comparable because controls were often very small and suffering from acute phosphate deficiency. Mycorrhizal plants were compared in three experiments with nonmycorrhizal plants given phosphate, and results agree quite well. Ross (127) found concentrations of nitrogen, calcium, and copper higher in mycorrhizal plants, and Holevas (64) found potassium concentrations lower and magnesium higher. In a soil containing very little available $\mathrm{P}, \mathrm{I}$ found that potassium concentrations of mycorrhizal plants were lower, and magnesium, manganese, copper, and zinc concentrations were higher than in the nonmycorrhizal plants.

Safir, Boyer \& Gerdemann $(129,130)$ measured the rate of water uptake into soyabeans recovering from temporary wilting, and found that mycorrhizal plants recovered more quickly than nonmycorrhizal plants. This was attributable to their better phosphorus nutrition (130), rather than to any specific effect of the mycorrhiza.

Meloh (90) showed that uptake of a much more complex substance (dihydrostreptomycin) was also greater in mycorrhizal than nonmycorrhizal maize.

\section{TAXONOMY OF ENDOGONE}

The anatomical similarity of VA infections has in the past led to the widespread assumption that most, if not all, these infections were caused by the same fungus. A variant with fine hyphae, few vesicles, and a tendency towards stranding of the intracellular mycelium was described by Greenall (55) and named Rhizophagus tenuis. A somewhat similar endophyte has been described in the roots of oats (142) and in some populations of Nardus stricta (4). Pandey \& Misra (118) recently described and named another endophyte occurring in Litchi chinensis.

Inoculation experiments with different Endogone types $(105,116)$ have shown that VA mycorrhiza are produced by several different Endogone species, probably even by different genera of fungi. According to Thaxter's (145) classification, all members of the genus Endogone form sporocarps, and species are distinguished by the structure of the sporocarps and the spores they contain. The discovery of different ectocarpic resting spores, attached singly to the extra-matrical mycelium of mycorrhizal roots has made some revision necessary. A definitive classification must probably await the culturing of these fungi, but for purposes of convenience some method of nomenclature is needed.

Gerdemann \& Trappe (49) recently completed a monograph on the Endo- 
gonaceae in the Pacific Northwest. According to them, four genera, Glomus, Sclerocystis, Gigaspora, and Acaulospora commonly form (VA) endomycorrhiza. Glomus species may be sporocarpic or not, with chlamydospores generally formed terminally on a single undifferentiated hypha. Chlamydospores of Sclerocystis borne in sporocarps, are arranged in a single layer around a central plexus of sterile hyphae. Gigaspora species bear the spores (probably azygospores) at the tip of a single, large, suspensor-like cell from which a slender hypha usually projects to the spore; they produce, in addition to the resting spores, smaller soil-borne vesicles of distinctive structure. The genus Acaulospora does not form sporocarps, and resting spores are borne laterally on a hypha terminating nearby in a large thin-walled vesicle. The name Endogone is confined to zygosporic species. At least one produces ectotrophic mycorrhiza, but several others are probably free-living.

Mosse \& Bowen (105) described nine types with apparently distinctive spores obtained from Australian and New Zealand soils by wet sieving. The spores differed in their cytoplasmic and wall structure, color, shape, and size, form of the subtending hypha, and in method of germination. We suggested a key for their practical identification, and gave descriptive names to the different spore types. An advantage of such a system is that any new spore type found can easily be incorporated. The name Endogone, now quite well established, is retained in this review for all VA endophytes; individual species, strains, or spore types are referred to under the name given in the original publication.

Some of the described types differ in only relatively minor characteristics, and are undoubtedly more closely related than others. Several differ consistently at the fine structure level. The spores are multinucleate. Germ tubes frequently anastomose (94), and there is, therefore, much opportunity for hybridization. Germ tubes of two types tested (laminate, and yellow vacuolate) did not anastomose on cellophane discs. Such observations could be extended, and the genetic homogeneity of a strain could also be checked by studying the variability of the progeny derived from inoculation with a single spore. The best evidence for the distinctness of species is that spores, thought to belong to a distinct spore type, reproduce similar progeny in "sterilized" soil containing a host plant.

The life history of honey-colored sessile spores (105) is so distinctive (98) that they almost certainly belong to the genus Acaulospora of Gerdemann \& Trappe (49). The resting spore forms as a lateral outgrowth from the swollen subtending hypha of another short-lived spore, whose contents migrate into the rapidly expanding resting spore. The fine structure of this spore exhibits several unusual features. It contains an organism, possibly an actinomycete, that divides by fission and appears to have an independent life cycle (99). The spore wall is very complex, consisting of up to seven layers, one with a very unusual periodic structure (100). Germ tubes arise from peripheral compartments formed within the split wall (98). Three other 
types [white and bulbous reticulate (105), and a very large reddish-black spore type first found in Nigeria (124)] germinate in a similar way and contain a similar periodic wall layer (125). The bulbous reticulate spore, and the Nigerian spore types have a characteristic swollen, pear-shaped, subtending hypha. The generic name Gigaspora (49) is proposed for this group. In all these spores, oil droplets, the characteristic storage material in spores of these fungi, are uniform, small, polygonal, and do not coalesce; they are separated by a fine cytoplasmic network (105). In another group now assigned to the genera Glomus and Sclerocystis (49), the oil droplets are spherical, coalesce readily, and differ greatly in size within a single spore. Old spores often contain a large central oil vacuole and only a thin peripheral layer of cytoplasm. To a third group, with small round spores formed in closely coherent masses of more than a hundred spores, but lacking a peridium, belong $E$. fasciculata (46) and several related forms described by Gilmore (50).

The Endogonaceae have taxonomic affinities with several other mucoraceous families (49). Their cytology, particularly that of the zygosporic and azygosporic species, is interesting but imperfectly understood. Bucholtz (29) described the delayed fusion of two nuclei in the zygospore, and the disintegration of smaller peripheral nuclei in the suspensor. In the yellow-vacuolate and honey-colored types nuclei divide by ingrowth of the inner nuclear membrane while the outer one remains intact, a method also found in some other Phycomycetes. Many nuclei disintegrate during the onset of dormancy.

\section{SPECIFICITY}

With the discovery of different Endogone endophytes, the question of specificity in VA mycorrhiza has been reinvestigated, both with regard to host range and to specific interactions between particular endophytes and their hosts. Earlier inoculation experiments with infected roots indicated that most VA endophytes could be transferred from one host to another. Only Tolle (147), using surface sterilized root sections, found some evidence of host specificity. The fungi from oat and barley roots could not be transmitted to or from other cereals, but those in wheat and rye were interchangeable. Inoculation experiments with surface-sterilized spores have confirmed that the host range of most endophytes is very wide. For instance, in my experiments, the yellow-vacuolate spore type (105) [Endogone mosseae (116)] formed VA mycorrhiza with onions, Coprosma, Liquidambar, Coleus, Fuchsia, clover, strawberry, apple, tomato, bean, pea, cucumber, Nardus and rye-grass. This type also infected tobacco $(9)$, soyabean $(129)$, citrus $(73,86)$, maize $(71)$, Aesculus indica (70) and barley (21). Other Endogone spp. will also infect many of these hosts.

Studies of the effect of different spore types on growth of the host are only beginning. Meloh (90) found that one endophyte (Vesikelmycorrhiza) im- 
proved growth of maize and oats in sand irrigated with a nutrient solution, while another (Sporokarpienmycorrhiza) reduced it. Daft \& Nicolson (34) found that three Endogone spore types differed little in their effects on maize, tomato, and tobacco in sand culture. The first indication that spore types might differ greatly in their effects was obtained when onions, preinoculated with the yellow-vacuolate spore type or sown on a cushion of inoculum (108), were planted in a nonsterile soil. Noninoculated control seedlings became uniformly infected with indigenous mycorrhizal fungi in two of the soils. In one this infection appreciably improved plant growth, in the other it did not, but in both soils the plants infected with the yellow-vacuolate spore type grew much better than noninoculated plants. A similar advantage of inoculated over indigenous strains was shown in two Brazilian soils with Paspalum notatum (101) as host plant, and with citrus (73).

Onions inoculated with seven different spore types showed a range of growth responses (102). Two strains produced little infection and slightly improved growth. Another strain caused abundant infection and a ten-fold increase in dry weight; the best strain increased weight fifteen-fold. In a different soil this strain was only fairly good, and four other strains surpassed it. Similar strain effects occurred with Paspalum.

Liming in general greatly increased the benefit of inoculation in two acid soils containing little available P (101). One spore type was more beneficial in the unlimed soil. Similar reactions to liming occurred in the same soil with another host plant. Two spore types did not get established in the unlimed soils. Such $\mathrm{pH}$ effect on the establishment of certain spore types (yellow-vacuolate, laminate, and RI) has now been observed in several soils (102, 107). It is independent of the host plant. Another spore type (honeycolored) infected rye-grass in only two out of five soils, irrespective of $\mathrm{pH}$ (102).

These results indicate that specificity exists in VA mycorrhiza, and that some Endogone strains are more beneficial than others in phosphate-deficient soils. The effectivity of a strain appears to depend more on its interaction with a particular soil than with a particular host.

Endogone strains also differed in their ability to improve zinc uptake of mycorrhizal peach seedlings (51).

Even the bacteria associated with inocula of different endophytes had different effects on the growth of nonmycorrhizal onions and rye-grass in phosphate-deficient soils (102). Compared with the effects of the endophytes themselves, these effects were small, but nevertheless statistically significant in onions; in rye-grass, washings from different spore inocula had quite large effects on plant weight. The outer layer of the spore wall of some Endogone species contains chitin, and is characteristically free from adhering soil debris. The outer wall layer of others is strongly attacked by bacteria, and may be lost altogether. If such differences in wall structure extend to the hyphae, different endophytes may well have different hyphosphere organisms characteristically associated with them. 


\section{ECOLOGY OF ENDOGONE}

The relatively simple technique of wet sieving and decanting (43) has been widely used to recover Endogone spores from soil. Modifications of the technique have been described $(111,117,128)$. Sutton \& Barron (143) recently described a technique depending on the adhesion of spores to a glass surface at the meniscus; this gave $94-98 \%$ recovery. Counting can be made easier by spreading the spore-containing fraction on "Dicel" cloth $(59,111)$.

Spore populations have been studied in different continents $(49,69,106$, 124), different ecological environments $(69,91,124,141)$ and in association with particular hosts $(27,122,133)$. Effects of manurial treatments $(26,35$, $59,71,106,122)$, of season $(59,87,91,124)$, light $(124)$, and water regime $(15,124)$ have also been examined in both pot and field experiments.

THE OCCURRENCE OF EXTRA-MATRICAL SPORES AND SPORE TYPES Most spore types seem to have a world-wide distribution. For instance those with honeycolored sessile spores, easily identifiable because of their unusual origin, have been found in Scotland (48), England (D. S. Hayman, private communication), Australia $(27,105)$, New Zealand (105), Pakistan (69), South Africa (58), Oregon (49), Florida (133), and in Brazil. Two other spore types (yellow-vacuolate and bulbous-reticulate) are as widespread. Even the crenulate spore type that we found in only one locality in South Australia (105), has now been reported from a restricted area of southeastern Queensland (27), from Nigeria (124), and Germany (H. Kruckelmann, private communication). It is interesting to speculate how such a uniform distribution has come about, as spores are probably too large to be carried into the upper atmosphere. They could, however, very easily be spread on plant roots.

Spores were generally more numerous and varied in cultivated than in noncultivated Australian and New Zealand soils (106). In West Pakistan certain spore types were more common in northern and mid-northern areas where soils contain substantial amounts of clay, than in arid southern regions where they are sandy (69). In six Nigerian areas with differing vegetation types, spores tended to be more numerous in the arid savannahs than in the moist forests, but some fluctuations and unexpected variations occurred in closely adjacent sites (124). Redhead concluded that at least 12 samples should be pooled to obtain a representative spore count. Most of the spores occurred in the top $15 \mathrm{~cm}$.

Although the host range of most spore types is wide, Bevege \& Richards (27) found one spore type predominantly associated with Araucaria cunninghamii in some 50 rain forest sites, but it was absent from this host in 16 plantations and 5 forest nursery sites. Porter \& Beute (122) found E. gigantea to be common in peanut, but rare in fescue soils. Adjacent fields on the Rothamsted farm, often carrying the same crop, have quite distinct spore populations. One field contains only a single spore type that is rare in a 
nearby field with a mixed population. This difference is not attributable to climate, and probably not to soil or any recent crop.

There are marked seasonal fluctuations in spore numbers in temperate climates. Hayman (59) found that the number of spores changed little from December to June, increased greatly in July, and decreased again slowly from September onwards. Mejstrik (91) found fewest spores in April and most in September in a Molinietum coeruleae association. Considerable seasonal fluctuations also occurred in Nigerian soils (124). Sutton \& Barron (143) counted spores in four Canadian soils growing wheat, maize, strawberries, and tomatoes, and in some comparable soils from England and Florida. They recovered from 20-90 spores/g air-dried soil, a much higher figure than that obtained by most other workers. Spores were least numerous in June and most in October, (strawberries were most in April), but seasonal fluctuations generally were small. More spores occurred within than between rows, and numbers decreased below $28 \mathrm{~cm}$.

The correlation between amounts of mycorrhizal infection and numbers of extra-matrical spores was studied in field plots (59) in wheat grown in field given various formalin and nitrogen treatments, and by Daft \& Nicolson (37) in maize grown in pots in sand culture with different phosphate treatments. Both found that numbers of external spores were closely related to root infection, and Daft \& Nicolson (37) concluded that, in their experiments, spore numbers were the measure of infection most closely related to plant weight. On the other hand, Redhead (124) thought that the number of spores in soil was not significantly correlated with root infection. Neither he nor I recovered any spores from some Nigerian rain forest and New Zealand bush soils where many plant species were strongly mycorrhizal.

EFFECTS OF LIGHT, WATER REGIME, AND MANURIAL TREATMENTS ON SPORE NUMBERS AND POPULATIONS Vesicles are mainly storage organs of the endophyte $(47,96)$ and extra-matrical spores probably have the same function. They are also reproductive stages relatively resistant to adverse conditions. Spore numbers are likely to reflect the nutritional status of the host and/or soil, and the onset of adverse conditions.

It has been inferred from various surveys that spores increase as a result of intermittent root growth (106), during seasons of slow root growth (87), and at sites where many rootlets die annually (124). Baylis (15) did not increase spore numbers by intermittent watering, but he halved them by cutting plants off at ground level. Sporocarps were fewer in logged than in undisturbed stands of sugar maple (68), but site variation was the largest variable. Spores associated with Khaya grown outdoors in large containers were most numerous after watering daily, and were reduced to $10 \%$ and $25 \%$ respectively by watering weekly and twice daily (waterlogging) (124). Heavy shading reduced spore formation by $80 \%$. Neither treatment affected root infection to the same extent. Bevege (26) reported similar effects of shading on spore numbers and infection. 
There is good evidence that large applications of nitrogen reduce spore formation in field plots $(59,111,122)$ and in pot tests $(26)$. External spores increased with added phosphate in field plots with noninoculated maize, presumably because the plants grew better, but if the maize was already mycorrhizal when planted, they decreased (71). Sporocarp formation was also greatly reduced by added phosphate $(64,97)$.

Prolonged fertilizer applications may cause changes in numbers and composition of the spore population $(59,106)$ in some soils. H. Kruckelmann (private communication) found that, in a sandy soil that had grown rye and potatoes for 50 years, unfertilized plots contained few spores, and numbers increased progressively in plots fertilized with NPK, farmyard manure, leaf mold, and farmyard manure plus NPK. However, on a heavy clay soil where wheat had been grown for over a hundred years, fertilizers had the opposite effect. Spore numbers, generally higher in this soil, were greatest in the unfertilized plot, and decreased progressively with additions of farmyard manure, NPK, and farmyard manure $+\mathbf{N}$.

INTERACTIONS WITH OTHER MICROORGANISMS Exudates from mycorrhizal roots are likely to differ from those of nonmycorrhizal roots because the nutritional status of the host plant may be altered and because the large volume of fungus tissue in mycorrhizal roots could affect root exudates more directly. Changes in root exudates would affect the rhizosphere microorganisms, and might make mycorrhizal roots easier to in vade or less susceptible to attack by other fungi. Such effects of ectotrophic mycorrhiza on root pathogens (85) and on nonpathogenic rhizosphere organisms (39) have been reported. Voigt (149) discusses the possibility that mycorrhiza might influence nitrogen fixation by free-living microorganisms.

Only four instances of interactions of VA mycorrhiza with other microorganisms have yet been reported, but other investigations are in progress. Asai (6) found that mycorrhiza seemed to be a necessary precondition for effective nodulation in many legumes. Successful nodulation is known to depend on an adequate phosphate supply, and many volcanic soils of Japan are very deficient in phosphate and some minor elements. In these experiments, however, the mycorrhizae were established from a 5-10 g inoculum of garden soil, which may itself have supplied necessary nutrients. If confirmed, Asai's results would be of considerable interest as many tropical soils are so phosphorus deficient that it is growth limiting, and plants do not respond to nitrogen until phosphate deficiency is corrected $(88,101)$.

Better nutrition of the host plant was also considered the reason for the larger number of TMV lesions in tobacco plants infected with Endogone (134). Daft \& Okusanya (38) found that amounts of extractable tomato aucuba, potato $\mathbf{X}$, and Arabis mosaic virus were greater in mycorrhizal plants, and again attributed this to better host nutrition.

Mycorrhizal tobacco plants were less damaged by Thielaviopsis basicola than nonmycorrhizal (9). Weight of the latter was reduced by $64 \%$, but 
that of mycorrhizal plants by only $28 \%$. Fewer chlamydospores of Thielaviopsis formed on mycorrhizal roots, and an extract of such roots inhibited chlamydospore formation by $80-100 \%$ in vitro.

\section{SOIL STERILIZATION}

Various methods of soil sterilization are used increasingly to kill pathogens, particularly in nurseries. Plant growth is generally improved by these treatments, but occasionally plants grow poorly after sterilization. For instance, zinc deficiency occurred in cotton after soil fumigation (151), and citrus grew badly in several nurseries for unexplained reasons $(83,84)$. Fumigation of some forest nurseries resulted in excessively vigorous unsuitable nursery trees, and this was corrected by inoculation with ectotrophic mycorrhizal fungi (65).

Kleinschmidt \& Gerdemann (73) investigated the growth of citrus seedlings in a nursery that had been fumigated with $400 \mathrm{lb} /$ acre of a 3:1 mixture of methyl bromide and chloropicrin. The seedlings grew unevenly in fumigated soil; the healthy ones were mycorrhizal, whereas stunted chlorotic ones were not. The stunted seedlings, transplanted into sterilized soil that had been inoculated with $E$. mosseae, became healthy, while the uninoculated seedlings remained stunted. Similar responses to inoculation were obtained in a fumigated field containing $63 \mathrm{lb} /$ acre available $P$ and $91 \mathrm{lb} /$ acre acid-soluble $P$. These are not particularly small amounts of phosphate. In a fumigated nursery in California heavy fertilization only partly overcame the poor growth of some citrus varieties, whereas inoculation with $E$. mosseae greatly improved growth (73). Possibly the mycorrhiza also helped in the uptake of some minor nutrient present at deficiency levels. Experiments with slash pine (148) showed in one of three soils, that adding $200 \mathrm{ppm} \mathrm{P}$ reduced plant growth, reduced mycorrhizal infection, and led to copper deficiency in the plants. If, as the frequently higher copper content of mycorrhizal plants suggests, mycorrhiza increase copper uptake, any treatment reducing mycorrhizal infection may lead, for biological rather than chemical reasons, to such unexpected deficiencies.

Fumigating soil cores with methyl bromide (32), or injecting soil to a depth of $0.9 \mathrm{~m}$ with methyl bromide and chloropicrin (128) killed the indigenous VA fungi in the soil. In other experiments, however, mycorrhizal infection of sweet gum seedlings was not greatly reduced in a coarse sieved forest soil fumigated with methyl bromide (41).

Effects of formalin, applied as a drench to field soil in situ were studied by Hayman (59). Following autumn application of the sterilant, mycorrhizal infection and spore numbers in the soil were very low until June, but then rose sharply and remained high throughout the following year. After repeated applications of formalin, infection was unexpectedly high, suggesting that strains resistant or tolerant to formalin may have been selected. Wilhelm (150) also reported heavy mycorrhizal infection in strawberries two years 
after soil fumigation with chlorobromopropene, and I have found the same after treatment with the nematocide, DD.

Nesheim \& Linn (114) examined effects of different concentrations of eight fungitoxicants, mixed into a steamed soil inoculated with $E$. fasciculata. All fungitoxicants at all concentrations considerably reduced infection of corn plants. Terraclor, Mylone, and Vapam suppressed it almost completely, Captan was least toxic.

\section{TRENDS}

The section headings of this paper show the different directions that research on VA mycorrhiza is taking. Most important from the practical point of view are the studies of VA mycor rhiza in relation to plant nutrition.

Much attention has been paid to the movement of phosphate and carbohydrates between fungus and host in ectotrophic mycorrhiza (57), and to phosphatase and phytase activity of the fungi in vitro. With vesicular-arbuscular mycorrhiza, perhaps because there is no sheath and the fungi cannot be grown in culture, most work has been done with the intact mycorrhizal system, and interest has centered around uptake mechanisms and the source of the extra nutrients absorbed from the soil. As a result it now seems very improbable that VA mycorrhiza utilize insoluble soil phosphate. They greatly increase $P$ uptake by a better exploration of the soil beyond the depletion zone and by hyphal proliferation in favorable micro-environments. Mycorrhizal roots also take up phosphate present in the soil solution at such low concentrations that it is practically unavailable to nonmycorrhizal roots of some plants. Finally, mycorrhizal fungi may help phosphate uptake of the host by competing with other microorganisms for soluble $\mathbf{P}$ present in plant debris.

If there is no net increase in a vailable phosphate, it may be questioned whether mycorrhiza do not simply bring about a more rapid exhaustion of limited supplies. While this may be so in the short term, more phosphate will gradually become available from soil reserves by purely chemical processes of desorption and/or solution as phosphate is taken out of the soil solution by mycorrhiza. Thus more phosphate will gradually come into circulation. The most important function of VA mycorrhiza in agriculture may be a better utilization of applied phosphate. In general $25 \%$ of added phosphate is used by the crop in the first year (33). The rest reverts to unavailable forms unless a reserve of potentially available $P$ is built up over the years by repeated fertilizer applications. If, because of their improved uptake, mycorrhizal plants can grow as well in a soil solution containing less available $P$ than would be required for equal growth of nonmycorrhizal plants, less fertilizer will be needed for the mycorrhizal plants, especially if they are infected with efficient strains of Endogone.

It is probable that the increased use of biocides may pinpoint some other nutrients affected by uptake through mycorrhiza. Others may be found by plant analysis. Such investigations and reported changes in enzyme activi- 
ties and respiration rates (139) must take into account that a phosphate-deficient plant is likely to differ from a normal plant in many respects. Only mycorrhizal and nonmycorrhizal plants with approximately similar phosphate content should be used for such comparisons.

While it is becoming clearer what advantages the plant may derive from VA mycorrhiza, the role of the plant in fungal metabolism remains quite unexplained. That it is crucial is evident because the fungus is an obligate symbiont. The autotroph in many symbiotic associations releases carbohydrate to the heterotroph that stores it, often in the form of polyols or complex sugars that cannot be metabolized by the autotroph (138). The fungi in ectotrophic mycorrhiza mainly accumulate mannitol and trehalose (57). Many observers have noted the disappearance of starch from infected host cells in VA mycorrhiza. There are reports that mycorrhizal roots contain more soluble sugars $(2,76)$, but others have found less $(139)$. In two-membered agar cultures, growth of the external mycelium in the medium was stimulated by inositol and glycerol (103), suggesting that these substances might be metabolized by the fungus. D. I. Bevege, G. D. Bowen \& M. Skinner (private communication), D. S. Hayman (private communication), and Hepper \& Mosse (63) did not find significantly more trehalose or mannitol in roots of various plants infected with VA mycorrhiza, nor any other striking differences in the carbohydrate pattern of infected and noninfected roots. Bevege et al found $74 \%$ of photosynthate in VA roots was in the form of soluble carbohydrate, and of the ${ }^{11} \mathrm{C}$ transferred to the external mycelium, $52 \%$ was recovered as protein and organic acid, and $30 \%$ in structural (cell wall) material. They concluded that the carbohydrate metabolism of VA mycorrhiza differs basically from that of the ectotrophic type.

Present evidence favors the view that mass flow, probably bidirectional, effectively connects the soil mycelium with the intracellular arbuscules. Fine structure $(20,132)$ clearly shows a complete collapse of arbuscules, leaving behind only remains of fungus wall. My pictures of young arbuscules show them to be full of cytoplasm and organelles. Both active and collapsed arbuscule branches can coexist in the same cell and fat globules apparently get from the fungus into the host cytoplasm (confirming light microscope observations) (89). Transfer of material from fungus to host cell also appears to occur by means of numerous exocytotic vesicles. Various barriers at the host/fungus interface could thus be by-passed. The technique of autoradiography would be very suitable to demonstrate such transfer of large molecules.

The feasibility of inoculation on a field scale is likely to receive further attention, both with the object of reinfecting sterilized soils and of introducing better strains of endophytes into natural soils. Both have already been done. Mycorrhizal plants can be grown in large containers or limited field plots to obtain enough heavily infected soil to inoculate a larger area (73), or preinoculated seedlings can be planted in the field $(71,72)$. The successful use of 
lyophilized, ground mycorrhizal roots as storable inoculum (66) raises interesting possibilities.

The need to obtain inoculum of different Endogone strains may renew interest in the culture of these fungi. Several workers $(82,140,147)$ have obtained limited hyphal growth and new vegetative spores from surface-sterilized mycorrhizal root pieces. At certain stages of root or plant development, such growth regularly occurs in tap-water agar, or other media of low nutrient content. Tolle (147) made the interesting observation that root exudates, but not root extracts, improved such growth. The subculture of detached hyphae has, however, never succeeded, and growth of the attached hyphae stops when the root pieces die. Failure has in the past been attributed to bacterial contamination, but this is incorrect. Extensive hyphal growth can readily be obtained from surface-sterilized, germinated spores. Germ tubes branch, produce vegetative spores, and grow several centimeters, but growth immediately stops if they are severed from the parent spore. Cut hyphae often produce a new growing point and make limited growth from the cut end by the method of wound healing described by Gerdemann (44). Unless they rejoin the hypha from which they were cut, or anastomose with another attached to a spore, no further growth will be made. Axenically germinated spores of the yellow-vacuolate type can easily be obtained (94), and probably offer the best starting point for attempts to culture Endogone. Barrett's (11) technique for producing cultures of "Rhizophagus" and their probable authenticity as VA endophytes, have been discussed by Gerdemann (47). Although the culture of VA endophytes presents a challenge, the reward is great for practical purposes and for comparative studies with other obligate and pathogenic fungi. 


\section{Literature Cited}

1. Agnihotri, V. P. 1970. Solubilization of insoluble phosphates by some soil fungi isolated from nursery seedbeds. Can. J. Microbiol. 16:877-80

2. Alexandrova, E. I. 1968. Mycorrhiza formation of barley in relation to the action of mineral fertilizers. [Russian] Uch. Zap. Perm. Ped. Inst. 64:274

3. Ali, B. 1969. Cytochemical and autoradiographic studies of mycorrhizal roots of Nardus. Arch. Mikrobiol. 68:236-45

4. Ali, B. 1969. Occurrence and characteristics of the vesicular-arbuscular endophyte of Nardus stricta. Nova Hedwigia 17:409-25

5. Asai, T. 1943. Die Bedeutung der Mykorrhiza füir das Pflanzenleben. Jap. J. Bot. 12:359-436

6. Asai, T. 1948. Über die Mykorrhizenbildung der leguminosen Pflanzen. Jap. J. Bot. 13:463-85

7. Asher, C. J., Loneragan, J. F. 1967. Responses of plants to phosphate concentration in solution culture. I. Growth and phosphorus content. Soil Sci. 103:225-33

8. Ballard, S. S., Dean, L. A. 1941. Soil studies with radioactive phosphorus: Significance of biological measurements of the retention of applied phosphorus by soils. Soil Sci. 52:173-82

9. Baltruschat, H., Schönbeck, F. 1972. Untersuchungen ïber den Einfluss der endotrophen Mycorrhiza auf die Chlamydosporenbildung von Thielaviopsis basicola in Tabakwurzeln. Phytopathol. $Z$. 74:358-61

10. Barley, K. P., Rovira, A. D. 1970. The influence of root hairs on the uptake of phosphate. Soil Sci. Plant Anal. 1:287-92

11. Barrett, J. T. 1961. Isolation, culture and host relation of the phycomycetoid vesicular-arbuscular endophyte Rhizophagus. Rec. Advan. Bot. 2: 1725 Univ. Toronto Press

12. Baylis, G. T. S. 1959. Effect of vesicular-arbuscular mycorrhizas on growth of Griselinia littoralis (Cornaceae). New Phytol. 58: 274-80

13. Baylis, G. T. S. 1967. Experiments on the ecological significance of phycomycetous mycorrhizas. New Phytol. 66:231-43

14. Baylis, G. T. S. 1969. Synthesis of mycorrhiza of Podocarpus and Agathis with Endogone spores. Nature, London 221:1267-68

15. Baylis, G. T. S. 1969. Host treatment and spore production by Endogone. N.Z. J. Bot. 7:173-74

16. Baylis, G. T. S. 1970 . Root hairs and phycomycetous mycorrhizas in phosphorus-deficient soil. Plant Soil 33:713-16

17. Baylis, G. T. S. 1971. Endogonaceous mycorrhizas synthesized in Leptospermum (Myrtaceae). N.Z. J. Bot. 9:293-96

18. Baylis, G. T. S. 1972. Minimum levels of phosphorus for nonmycorrhizal plants. Plant Soil 36: 233-34

19. Baylis, G. T. S., McNabb, R. F. R., Morrison, T. M. 1963. The mycorrhizal nodules of podocarps. Trans. Brit. Mycol. Soc. 46:37884

20. Becking, J. H. 1965. Nitrogen fixation and mycorrhiza in Podocarpus root nodules. Plant Soil 23: 213-26

21. Benians, G. J., Barber, D. A. 1972. Influence of infection with Endogone mycorrhiza on the absorption of phosphate by barley plants. Letcombe Lab. Ann. Rept. 1971: 7-9

22. Bertrand, D. 1972. Interactions entre éléments minereaux et microorganisms du sol. Rev. Ecol. Biol. Sol. 9:349-96

23. Beslow, D. T., Hacskaylo, E., Melhuish, J. H. 1970. Effects of environment on beaded root development in red maple. Bull. Torrey Bot. Club 97:248-52

24. Bevege, D. I. 1968. A rapid technique for clearing tannins and staining intact roots for detection of mycorrhizas caused by Endogone spp., and some records of infection in Australasian plants. Trans. Brit. Mycol. Soc. 51:80810

25. Bevege, D. I. 1970. Vesicular-arbuscular mycorrhizas of Araucaria cunninghamii and their role in nitrogen and phosphorus nutrition. 
Paper given at 42 nd Congr. Austr. N.Z. Assoc. Adv. Sci. Sect. 12 (microfiche)

26. Bevege, D. I. 1972. Vesicular-arbuscular mycorrhizas of Araucaria: Aspects of their ecology and physiology and role in nitrogen fixation. Ph.D. Thesis, Univ. of New England, Armidale, N.S.W.

27. Bevege, D. I., Richards, B. N. 1971. Some aspects of Endogone forming mycorrhizas with Hoop Pine (Araucaria cunninghamii Ait.). $X V$ IUFRO Congr. Sect. 24

28. Bowen, G. D., Rovira, A. D. 1968. The influence of micro-organisms on growth and metabolism of plant roots. In: Root Growth, 170-99. Ed. W. J. Whittington, Butterworths: London

29. Bucholtz, F. 1912. Beiträge zur Kenntniss der Gattung Endogone Link. Beih. Bot. Centralbl. Ser. II 29:147-224

30. Clark, F. B. 1963. Endotrophic mycorrhizae influence yellowpoplar seedling growth. Science 140: $1220-21$

31. Clark, F. B. 1964. Micro-organisms and soil structure affect yellow-poplar growth. U.S. Forest Serv. Res. Paper, CS-9:12

32. Clark, F. B. 1969. Endotrophic mycorrhizal infection of tree seedlings with Endogone spores. Forest Sci. 15:134-37

33. Cooke, G. W. 1965. The responses of crops to phosphate fertilizers in relation to soluble phosphorus in soils. In: Soil Phosphorus, Min. Ag. Fish. Tech. Bull. 13:64-74

34. Daft, M. J., Nicolson, T. H. 1966. Effect of Endogone mycorrhiza on plant growth. New Phytol. 65: 343-50

35. Daft, M. J. Nicolson, T. H. 1969. Effect of Endogone mycorrhiza on plant growth. II. Influence of soluble phosphate on endophyte and host in maize. New Phytol. 68: 945-52

36. Daft, M. J., Nicolson, T. H. 1969. Effect of Endogone mycorrhiza on plant growth. III. Influence of inoculum concentration on growth and infection in tomato. New Phytol. 68:953-61

37. Daft, M. J., Nicolson, T. H. 1972. Effect of Endogone mycorrhiza on plant growth. IV. Quantitative relationships between the growth of the host and the development of the endophyte in tomato and maize. New Phytol. 71:287-95

38. Daft, M. J., Okusanya, B. O. 1973. Effect of Endogone mycorrhiza on plant growth. V. Influence of infection on the multiplication of virus in tomato, petunia and strawberry. New Phytol. 72: In press

39. Davey, C. B. 1971. Nonpathogenic organisms associated with mycorrhizae. In: Mycorrhizae, ed. E. Hacskaylo., US Dep. Ag. Misc. Publ. 1189:114-21

40. Deal, D. R., Boothroyd, C. W. Mai, W. F. 1972. Replanting of vineyards and its relationship to vesicular-arbuscular mycorrhiza. Phytopathology 62:172-75

41. Filer, T. H., Toole, E. R. 1968. Effect of methyl bromide on mycorrhizae and growth of sweet gum seedlings. Plant Dis. Reptr. 52:483-85

42. Fried, M. 1953. The feeding power of plants for phosphates. Proc. Soil Sci. Soc. Am. 17:35759

43. Gerdemann, J. W. 1955. Relation of a large soil-borne spore to phycomycetous mycorrhizal infections. Mycologia 47:619-32

44. Gerdemann, J. W. 1955. Wound healing of hyphae in a phycomycetous mycorrhizal fungus. Mycologia 47:916-18

45. Gerdemann, J. W. 1964. The effect of mycorrhiza on the growth of maize. Mycologia 56: 342-49

46. Gerdemann, J. W. 1965 . Vesicular-arbuscular mycorrhizae formed on maize and tulip-tree by Endogone fasciculata. Mycologia 57: $562-75$

47. Gerdemann, J. W. 1968. Vesicular-arbuscular mycorrhiza and plant growth. Ann. Rev. Phytopathol. 6:397-418

48. Gerdemann, J. W., Nicolson, T. H. 1963. Spores of mycorrhizal Endogone species extracted from soil by wet sieving and decanting. Trans. Brit. Mycol. Soc. 46:23544

49. Gerdemann, J. W., Trappe, J. M. 1973. The Endogonaceae in the 
Pacific Northwest. Mycologia Memoirs. In press

50. Gilmore, A. E. 1968. Phycomycetous mycorrhizal organisms collected by open-pot culture methods. Hilgardia 39:87-105

51. Gilmore, A. E. 1971. The influence of endotrophic mycorrhizae on the growth of peach seedlings. J. Am. Soc. Hort. Sci. 96:35-38

52. Gray, L. E., Gerdemann, J. W. 1967. Influence of vesicular-arbuscular mycorrhiza on the uptake of phosphorus-32 by Liriodendron tulipifera and Liquidambar styraciflua. Nature, London 213:106-7

53. Gray, L. E., Gerdemann, J. W. 1969. Uptake of phosphorus-32 by vesicular-arbuscular mycorrhizae. Plant Soil 30:415-22

54. Greaves, M. P., Wilson, M. J. 1970. The degradation of nucleic acid and montmorillonite-nucleic acid complexes by soil micro-organisms. Soil Biol. Biochem. 2: 257-68

55. Greenall, J. M. 1963. The mycorrhizal endophytes of Griselinia littoralis (Cornaceae). N.Z. J. Bot. $1: 389-400$

56. Harley, J. L. 1950. Recent progress in the study of endotrophic mycorrhiza. New Phytol. 49:21347

57. Harley, J. L. 1969. The biology of mycorrhiza. 2nd ed., Leonard Hill: London

58. Hattingh, M. J. 1972. A note on the fungus Endogone. J. S. Afr. Bot. 38:29-31

59. Hayman, D. S. 1970. Endogone spore numbers in soil and vesicular-arbuscular mycorrhiza in wheat as influenced by season and soil treatment. Trans. Brit. Mycol. Soc. 54:53-63

60. Hayman, D. S., Mosse, B. 1971. Plant growth responses to vesicular-arbuscular mycorrhiza. I. Growth of Endogone-inoculated plants in phosphate-deficient soils. New Phytol. 70:19-27

61. Hayman, D. S., Mosse, B. 1972. Plant growth responses to vesicular-arbuscular mycorrhiza. III. Increased uptake of labile $P$ from soil. New Phytol. 71:41-47

62. Hayman, D. S., Mosse, B. 1972. The role of vesicular-arbuscular mycorrhiza in the removal of phosphorus from soil by plant roots. Rev. Ecol. Biol. Sol. 9: 463-70

63. Hepper, C., Mosse, B. 1973. Trehalose and mannitol content of roots with Endogone mycorrhiza. Rep. Rothamsted Exp. Sta. 1972

64. Holevas, C. D. 1966. The effect of a vesicular-arbuscular mycorrhiza on the uptake of soil phosphorus by strawberry (Fragaria sp. var. Cambridge Favourite). J. Hort. Sci. 41:57-64

65. Iyer, J. G., Lipas, E., Chesters, G. 1969. Correction of mycotrophic deficiencies of tree nursery stock produced on biocide-treated soils. In: Mycorrhizae, ed. E. Hacskaylo, U S Dep. Agr. Misc. Publ. 1189:233-38

66. Jackson, N. E., Franklin, R. E., Miller, R. H. 1972. Effects of VA mycorrhizae on growth and phosphorus content of three agronomic crops. Proc. Soil Sci. Soc. Am. 36: 64-67

67. Kalra, Y. P. 1971. Different behaviour of crop species in phosphate absorption. Plant Soil 34:535-39

68. Kessler, K. J., Blank, R. W. 1972. Endogone sporocarps associated with sugar maple. Mycologia 64: 634-38

69. Khan, A. G. 1971. Occurrence of Endogone species in West Pakistan soils. Trans. Brit. Mycol. Soc. 56: 217-24

70. Khan, A. G. 1972. Podocarp-like mycorrhizal nodules in Aesculus indica. Ann. Bot. 36:229-38

71. Khan, A. G. 1972. The effect of vesicular-arbuscular mycorrhizal associations on growth of cereals. I. Effects on maize growth. New Phytol. 71:613-19

72. Khan, A. G. 1973. The effect of vesicular-arbuscular mycorrhizal associations on growth of cereals. II. Effects on wheat growth. J. Appl. Biol. In press

73. Kleinschmidt, G. D., Gerdemann, J. W. 1972. Stunting of citrus seedlings in fumigated nursery soils related to the absence of endomycorrhiza. Phytopathology 62: 1447-53

74. Kirillova, V. P. 1968. Effect of application of mineral fertilizers on the formation of mycorrhiza 
in Agrostis tenuis, Alopecurus pratensis and other plants which are components of a grass meadow community of the Karelian isthmus. [Russian] Uch. Zap. Perm. Ped. Inst. 64:279-82. (Chem. Abstr. 1970. 73:3112 f)

75. Khrushcheva, E. R. 1960 . Conditions favourable for the formation of mycorrhiza of maize. [Russian] Agrobiologiya 4:588-93

76. Khrushcheva, E. R. 1960 . The mycorrhiza of wheat and its importance for the growth and development of the plant. [Russian] lzv. Akad. Nauk. Ser. Biol. 2: 220-39. Soils Fert. 1960. 23: abstr. 1220

77. Kryuger, L. V., et al. 1968. Method for determining the amount of infection in endotrophic mycorrhiza and for quantitative characterisation of mycosymbiotrophism in plant associations. [Russian] Uch. Zap. Perm. Ped. Inst. $64: 260$

78. Lanowska, J. 1962. An investigation on the influence of fertilizers on the occurrence of mycorrhiza in Cucurbita pepo. [Polish] Acta Microbiol. Pol. 11:349-58

79. Lanowska, J. 1966. Effect of different sources of nitrogen on the development of mycorrhiza in Pisum sativum. [Polish] Pan $\mathrm{Pu}$ lawski 21:365-86

80. Laycock, D. H. 1945. Preliminary investigations into the function of the endotrophic mycorrhiza of Theobroma cacao L. Trop. Agr. 22:77-80

81. Lyness, A. S. 1936. Varietal differences in the phosphorus feeding capacity of plants. Plant Physiol. 11:665-88

82. Magrou, J. 1946. Sur la culture de quelques champignons de micorrhizes à arbuscules et à vésicules. Rev. Gén. Bot. 53:49-77

83. Martin, J. P., et al. 1953. Effect of soil fumigation on growth and chemical composition of citrus plants. Soil Sci. 75:137-51

84. Martin, J. P., Baines, R. C., Page, A. L. 1963. Observations on the occasional temporary growth inhibition of citrus seedlings following heat or fumigation treatment of soil. Soil Sci. 95:175-85

85. Marx, D. H. 1971. Ectomycorrhi- zae as biological deterrents to pathogenic root infections. In: Mycorrhizae, ed. E. Hacskaylo, U S Dep. Agr. Misc. Publ. 1189: 81-96

86. Marx, D. H., Bryan, W. C., Campbell, W. A. 1971. Effect of endomycorrhiza formed by Endogone mosseae on growth of citrus. Mycologia 63:1222-26

87. Mason, D. T. 1964. A survey of numbers of Endogone spores in soil cropped with barley, raspberry and strawberry. Hort. Res. 4:98-103

88. McClung, A. C., et al. 1957. Preliminary fertility studies on "campos cerrados' soils in Brazil. IBEC Res. Inst. Bull. 13:5-17

89. McLennan, E. I. 1926. The endophytic fungus of Lolium. II. The mycorrhiza on the roots of $\mathrm{Lo}$ lium temulentum $\mathrm{L}$. with a discussion of the physiological relationships of the organisms concerned. Ann. Bot. 40:43-68

90. Meloh, K. A. 1963. Untersuchungen zur Biologie der endotrophen Mycorrhiza bei Zea mays L. und Avena sativa L. Arch. Mikrobiol. 46:369-81

91. Mejstrick, V. K. 1972. Vesiculararbuscular mycorrhizas of the species of a Molinietum coeruleae L. I. association: the ecology. New Phytol. 71:883-90

92. Morrison, T. M., English, D. A. 1967. The significance of mycorrhizal nodules of Agathis australis. New Phytol. 66:245-50

93. Mosse, B. 1957. Growth and chemical composition of mycorrhizal and non-mycorrhizal apples. Nature, London 179:922-24

94. Mosse, B. 1959. The regular germination of resting spores and some observations on the growth requirements of an Endogone sp. causing vesicular-arbuscular mycorrhiza. Trans. Brit. Mycol. Soc. 42:274-86

95. Mosse, B. 1962. The establishment of vesicular-arbuscular mycorrhiza under aseptic conditions. J. Gen. Microbiol. 27:509-20

96. Mosse, B. 1963 . Vesicular-arbuscular mycorrhiza: an extreme form of fungal adaptation. In: Symbiotic Associations, ed. P. S. Nutman, B. Mosse, Symp. Soc. 
Gen. Microbiol. 13:146-70. Cambridge Univ. Press

97. Mosse, B. 1967. Effects of host nutrient status on mycorrhizal infection. Rep. Rothamsted Exp. Sta. 1966, p. 79

98. Mosse, B. 1970. Honey-coloured, sessile Endogone spores. I. Life history. Arch. Mikrobiol. 70:16775

99. Mosse, B. 1970. Honey-coloured, sessile Endogone spores. II. Changes in fine structure during spore development. Arch. Mikrobiol. 74:129-45

100. Mosse, B. 1970. Honey-coloured, sessile Endogone spores. III. Wall structure. Arch. Mikrobiol. 74: 149-59

101. Mosse, B. 1972. Effects of different Endogone strains on the growth of Paspalum notatum. Nature, London 239:221-23

102. Mosse, B. 1972. The influence of soil type and Endogone strain on the growth of mycorrhizal plants in phosphate deficient soils. Rev. Ecol. Biol. Sol. 9:529-37

103. Mosse, B. 1972. Growth of Endogone mycorrhiza in agar medium. Rep. Rothamsted Exp. Sta. 1971, p. 93

104. Mosse, B. 1973. Plant growth responses to vesicular-arbuscular mycorrhiza. IV. In soil given additional phosphate. New Phytol. 72: 127-36

105. Mosse, B., Bowen, G. D. 1968. A key to the recognition of some $E n$ dogone spore types. Trans. Brit. Mycol. Soc. 51:469-83

106. Mosse, B., Bowen, G. D. 1968. The distribution of Endogone spores in some Australian and New Zealand soils and in an experimental field soil at Rothamsted. Trans. Brit. Mycol. Soc. 51:485-92

107. Mosse, B., Hayman, D. S. 1970. Effect of Endogone mycorrhiza on plant growth. Rep. Rothamsted Exp. Sta. 1969, p. 95-96

108. Mosse, B., Hayman, D. S. 1971. Plant growth responses to vesicular-arbuscular mycorrhiza. II. In unsterilised field soils. New Phytol. 70:29-34

109. Mosse, B., Hayman, D. S., Amold, D. 1973. Plant growth responses to vesicular-arbuscular mycor- rhiza. V. Phosphate uptake from ${ }^{23} \mathrm{P}$ labelled soil solution by three plant species. New Phytol. 72: In press

110. Mosse, B., Hayman, D. S., Ide, G. J. 1969. Growth responses of plants in unsterilized soil to inoculation with vesicular-arbuscular mycorrhiza. Nature, London 224: 1031-32

111. Mosse, B., Jones, G. W. 1968. Separation of Endogone spores from organic soil debris by differential sedimentation on gelatine columns. Trans. Brit. Mycol. Soc. 51:604-8

112. Mosse, B., Phillips, J. M. 1971. The influence of phosphate and other nutrients on the development of vesicular-arbuscular mycorrhiza in culture. J. Gen. Micro. biol. 69:157-66

113. Murdoch, C. L., Jackobs, J. A., Gerdemann, J. W. 1967. Utilization of phosphorus sources of different availability by mycorrhizal and non-mycorrhizal maize. Plant Soil 27:329-34

114. Nesheim, O. N., Linn, M. B. 1969. Deleterious effects of certain fungitoxicants on the formation of mycorrhiza on corn by Endogone. fasciculata and on corn root development. Phytopathology 59: 297-300

115. Nicolson, T. H. 1967. Vesiculararbuscular mycorrhiza-a universal plant symbiosis. Sci. Progr. Oxf. 55:561-68

116. Nicolson, T. H., Gerdemann, J. W. 1968. Mycorrhizal Endogone species. Mycologia 60:313-25

117. Ohms, R. E. 1957. A flotation method for collecting spores of a phycomycetous mycorrhizal parasite from soil. Phytopathology 47:751-52

118. Pandey, S., Misra, A. P. 1971. Rhizophagus in mycorrhizal association with Litchi chinensis Sonn, Mycopath. Mycol. Appl. 45:33754

119. Peuss, H. 1958. Untersuchungen zur Okologie und Bedeutung der Tabakmycorrhiza. Arch. Mikro. biol. 29:112-42

120. Peyronel, B. 1940. Prime osservazioni sui rapporti tra luce e simbiosi micorrizica. Annuar. Lab. Chanousia Giardino Botanico 
dell'Ordine Mauriziana al Piccolo San Bernardo 4:3-19

121. Phillips, J. M., Hayman, D. S. 1970. Improved procedures for clearing roots and staining parasitic and vesicular-arbuscular mycorrhizal fungi for rapid assessment of infection. Trans. Brit. Mycol. Soc. 55:158-61

122. Porter, D. M., Beute, M. K. 1972. Endogone species in roots of Virginia type peanuts. Phytopathology 62:783 (abstr.)

123. Possingham, J. V., Obbink, J. G. 1971. Endotrophic mycorrhiza and the nutrition of grape vines. Vitis 10:120-30

124. Redhead, J. F. 1971. Endogone and endotrophic mycorrhizae in Nigeria. $X V$ IUFRO Congr., Sec. 24

125. Redhead, J. F., Old, K. M., Nicolson, T. H. 1973. A new species of mycorrhizal Endogone from Nigeria with a distinctive spore wall. New Phytol. 72: In press

126. Rorison, I. H. 1968. The response to phosphorus of some ecologically distinct plant species. I. Growth rates and phosphorus absorption. New Phytol. 67:913-23

127. Ross, J. P. 1971. Effect of phosphate fertilization on yield of mycorrhizal and non-mycorrhizal soybeans. Phytopathology 61: 1400-03

128. Ross, J. P., Harper, J. A. 1970. Effect of Endogone mycorrhiza on soybean yields. Phytopathology 60:1552-56

129. Safir, G. R., Boyer, J. S., Gerdemann, J. W. 1971. Mycorrhizal enhancement of water transport in soybean. Science 172:581-83

130. Safir, G. R., Boyer, J. S., Gerdemann, J. W. 1972. Nutrient status and mycorrhizal enhancement of water transport in soybean. Plant Physiol. 49:700-03

131. Sanders, F. E., Tinker, P. B. 1971. Mechanism of absorption of phosphate from soil by Endogone mycorrhizas. Nature, London 233: 278-79

132. Scannerini, S., Bellando, M. 1968. Sull' ultrastruttura delle micorrize endotrofiche di Ornithogalum umbellatum $\mathrm{L}$. in attivita vegetativa. Atti. Accad. Sci. Torino 102: 795-809
133. Schenck, N. C., Hinson, K. 1971. Endotrophic vesicular-arbuscular mycorrhizae on soybean in Florida. Mycologia 63:672-75

134. Schonbeck, F., Schinzer, U. 1972. Untersuchungen ïber den Einfluss der endotrophen Mycorrhiza auf die TMV-Läsionenbildung in $\mathbf{N i}$ cotiana tabacum L. (var. Xanthinc). Phytopathol. Z. 73:78-80

135. Shelonina, I. M. 1959. Effect of bacterial fertilisers on mycorrhiza formation in maize. [Russian] $\mathrm{Ku}$ kuruza 4:42-43; (Rev. Appl. Mycol., 39:306 1960.)

136. Shemakhanova, N. M., Mazur, O. P. 1968. Mycorrhiza in walnut (Juglans regia $\mathrm{L}$.) and conditions of its formation. [Russian] $12 v$. Akad. Nauk SSSR Ser. Biol. 41: 517-29

137. Smith, S. N. 1934. Responses of inbred lines and crosses in maize to variations of nitrogen and phosphorus supplied as nutrients. J. Am. Soc. Agron. 26:785-804

138. Smith, D., Muscatine, L., Lewis, D. 1969. Carbohydrate movement from autotrophs to heterotrophs in parasitic and mutualistic symbiosis. Biol. Rev. 44:17-90

139. Sogina, I. I. 1970. Mycorrhiza of maize and its effects on some physiological processes [Russian]. Autoreferat Diss.

140. Stahl, M. 1949. Die Mycorrhiza der Lebermoose mit besonderer Beriicksichtigung der thallosen Formen. Planta 37:103-48

141. Stelz, T. 1968. Mycorrhizes et végétation des pelouses calcaires. Rev. Socs. sav. haute-Normandie 50:69-85

142. Strzemska, J. 1955. Investigations on the mycorrhiza in corn plants. [Polish] Acta Microbiol. Pol. 4: 191-204

143. Sutton, J. C., Barron, G. L. 1972. Population dynamics of Endogone spores in soil. Can. J. Bot. 50: 1909-14

144. Tardieux-Roche, A., Tardieux, $P$. 1970. La biosynthèse des phosphates condensés par la microflore du sol et son rôle dans la nutrition des vegetaux. Ann. Agron. 21:305-14

145. Thaxter, R. 1922. A revision of the Endogoneae. Proc. Am. Acad. Arts. Sci. 57:291-350 
146. Thomas, W. 1930. The feeding power of plants. Plant Physiol. 5: 443-89

147. Tolle, R. 1958. Untersuchungen iiber die Pseudomycorrhiza von Gramineen. Arch. Mikrobiol. 30: 285-303

148. van Lear, D. H., Smith, W. H. 1972. Relationships between macro- and micro-nutrient nutrition of slash pine on three coastal plain soils. Plant Soil 36:33147

149. Voigt, G. K. 1971. Mycorrhizae and nutrient mobilization. In: Mycorrhizae ed. E. Hacskaylo, U S Dep. Agr. Misc. Publ. 1189: 122-31

150. Wilhelm, S. 1959. Parasitism and pathogenesis of root-disease fungi. In: Plant Pathology 1908-58, 356-66 ed. C. S. Holton et al., Univ. Wisconsin Press
151. Wilhelm, S., George, A., Pendery, W. 1967. Zinc deficiency in cotton induced by chloropicrin-methyl bromide soil fumigation to control Verticillium wilt. Phytopathology 57: 103 (abstr.)

152. Winter, A. G., Birgel, G. 1953. Untersuchungen über die Verbreitung, Ookologie und funktionelle Bedeutung der endotrophen $\mathbf{M y}$ korrhiza bei gärtnerischen Kulturpflanzen. Naturwissenschaften 40:393-94

153. Winter, A. G., Meloh, K. A. 1958. Untersuchungen iiber den Einfluss der endotrophen Mykorrhiza auf die Entwicklung von Zea mays L. Naturwissenschaften 45:319

154. Wuenscher, M. L., Gerloff, G. C. 1971. Growth of Andropogon scoparius (Little Bluestem) in phosphorus deficient soils. New Phytol. 70:1035-42 